\title{
NATURAL AND RESOURCE POTENTIAL OF THE REGION \\ AS PART OF INVESTMENT RESOURCES: EVIDENCE FROM THE GANJA-GAZAKH ECONOMIC REGION OF AZERBAIJAN"
}

\section{Asif Abuzar oglu HASANOV a, Inga V. KHAN-KHOYSKAYA ${ }^{\text {b, }}$, Aytekin Maharram gizi BAGIROVA ${ }^{\mathrm{c}}$}

\author{
a Azerbaijan State Agricultural University, Ganja, Republic of Azerbaijan \\ asifhasanov563@gmail.com \\ https://orcid.org/0000-0001-8762-5721 \\ ${ }^{\mathrm{b}}$ Azerbaijan State Agricultural University, Ganja, Republic of Azerbaijan \\ inga.kasilova@gmail.com \\ https://orcid.org/0000-0002-7624-0268
}

c Azerbaijan State Agricultural University, Ganja, Republic of Azerbaijan aytekinb@mail.ru https://orcid.org/0000-0003-4832-3514

- Corresponding author

\section{Article history:}

Article No. 25/2020

Received 15 January 2020

Received in revised form

17 February 2020

Accepted 16 March 2020

Available online

30 March 2020

JEL classification: R11, R58

Keywords: economic region, resources, potential, investment activities

\begin{abstract}
Subject The article describes natural resource capabilities of the Ganja-Gazakh Economic Region of Azerbaijan, with the diversity, quantity, quality, exploration degree and parameters of raw material source exploitation in the region being a cornerstone for this.

Objectives The study is to promote such projects that involve an increase in both internal and external investment in the Ganja-Gazakh Economic Region. To achieve that, local authorities should improve the investment climate and prepare the acts - decisions within their areas of expertise that promote investments in the modernization of the industrial infrastructure and ensure that investors have access to the reliable information about the natural and resources potential of the region and its ecological situation.

Methods The study is based on the systems analysis. The emergence principle, also known as the principle of irreducibility, i.e. properties of a whole are not equal to a sum of properties of its components, in our opinion, may serve as means of guidance in use of natural and resource potential in order to face challenges of investing in a specific region.

Results We assessed the stock of the main natural resources types and revealed that the region's environment severely suffered from the depletion and pollution aggravated by a growth in the consumption of natural resources consumption grows.

Conclusions and Relevance It is necessary to boost investment not only in projects for further use of natural resources but also in priority programs aiming at the recovery and preservation of the environment.
\end{abstract}

Please cite this article as: Hasanov A.A., Khan-Khoyskaya I.V., Bagirova A.M. Natural and Resource Potential of the Region as Part of Investment Resources: Evidence from the Ganja-Gazakh Economic Region of Azerbaijan. Digest Finance, 2020, vol. 25, iss. 1, pp. 17-29.

https://doi.org/10.24891/df.25.1.17

The English text is provided by the authors

The editor-in-charge of this article was Irina M. Vechkanova

\section{Introduction}

For the source article, please refer to: Гасанов А.A., Хан-Хойская И.В., Багирова А.М. Природно-ресурсный потенциал региона как составляющая инвестиционных ресурсов (на примере Гянджа-Газахского экономического района Азербайджана). Региональная экономика: теория и
In January 2019, the Azerbaijan government launched a new five-year State program for the socio-economic development in the Republic 
of Azerbaijan for 2019-2023 ${ }^{1}$. This document is a sustainable development strategy for the Republic of Azerbaijan in accordance with the Strategic Roadmaps of National Economy and main sectors of the economy ${ }^{2}$. The Government primarily addresses the regional investment. The State investment policy in regions is implemented through infrastructure projects. However, according to the Head of the State, local executive authorities should set up a scope of works in order to attract investments, create a favorable investment climate in the region regardless its size, small or big, centered or peripherical $^{3}$. In order to attract investments to a certain region, in the authors' view, local executive authorities must conduct a thorough analysis and evaluate the region's natural and resource potential. This assessment must be given after a serious and extensive research not only of the economic but also of the ecological situation in the region is conducted. In that regard, local executive authorities should work closely with both businessmen and State structures, as well as scientific organizations and specialists to train professional personnel for the country [2].

Research on geographical distribution of natural resources in the country allows to develop productive powers of the regions. Nonetheless, the effective distribution of productive powers leads to the rational use of the region's resource potential [3]. They should evaluate the natural and resource potential of each region to be used effectively, measure its participation in the country's economic turnover in order to secure its sustainable economic development ${ }^{4}$. The

\footnotetext{
${ }^{1}$ State Program of Socio-Economic Development of the Regions of the Republic of Azerbaijan, 2019-2023. Decree of the President of the Republic of Azerbaijan of January 29, 2019. SP SEDR RA, 2019. URL: https://president.az/articles/31697

${ }^{2}$ On the Main Directions of the Strategic Road Map on National Economy and Major Sectors of the Economy. Decree of the President of the Republic of Azerbaijan, 16 March 2016. SP SRMNE, 2016. URL: https://ru.president.az/articles/21953

${ }^{3}$ Overview of the World Bank in Azerbaijan. World Bank, 2019. URL: https://www.worldbank.org/en/country/azerbaijan/overview

${ }^{4}$ United Nations Department of Economic and Social Affairs. Global Sustainable Development Report. UN DESA, 2019. URL: https://www.un.org/development/desa/publications/globalsustainable-development-report-2019.html
}

relevance of this article is that it studies processes taking place in the Ganja-Gazakh Economic Region. Based on the ecological and economic evaluation of the natural and resource potential of the Ganja-Gazakh Economic Region, we performed a comprehensive analysis of its actual situation; possibilities for the accelerated development of the contemporary mineral-raw complex and expanding of the investment base ${ }^{5}$.

We aim to prepare valid proposals and recommendations on how to attract investments in order to increase the effective use of the region's natural and resource potential and improve its ecological situation ${ }^{6}$. The main objectives of research are directives for the efficiency enhancement of the contemporary mineral-raw complex as a production system that includes leading industries of the region. Moreover, the raw material resource exploration must always be accompanied with the reliable environmental and economical evaluation of the natural and resource potential of the GanjaGazakh Economic Region.

The Ganja-Gazakh Economic Region, including the districts (rayons) of Ağstafa, Dashkesan, Gadabay, Goranboy, Göygöl, Gazakh, Samukh, Shamkir, Tovuz and cities of Ganja and Naftalan, has a high economic significance for the whole country. The territory of the Ganja-Gazakh Economic Region has the favorable economicgeographical location, making $14.4 \%$ of the country's territory, or $12,300 \mathrm{~m}^{2}$. Enjoying favorable natural conditions and economic andgeographical location, this area is densely populated - 1,274.8 thousand people, with the population density being 104 inhabitants per $1 \mathrm{~km}^{2}$. The terrain of the Gandja-Gazakh economic region with its elevation amplitude of

\footnotetext{
${ }^{5}$ Foreign Direct Investment (FDI) in Azerbaijan. Export Enterprises SA. Nordea, Nordea Trade and the Nordea Logo, 2019. URL: https://www.nordeatrade.com/en/explore-newmarket/azerbaijan/investment

${ }^{6}$ Investment Framework and Opportunities in Azerbaijan Procedures Relative to Foreign Investment. Export Enterprises SA. Nordea, Nordea Trade and the Nordea Logo, 2019. URL: https:/www.nordeatrade.com/en/explore-newmarket/azerbaijan/investment-environment
} 
3,500 m creates favorable conditions for life and use $^{7}$.

The research database consists of materials taken from the State Statistics Committee, Ministry of Ecology and Natural Resources, State Earth and Cartography Committee, Ministry of Economic Development, Ministry of Agriculture, as well as from the Internet ${ }^{8}$. The theoretical part herein was based on the local and international experience, using the synthesis and comparative analysis. The article contains research that has been conducted through the systems analysis, comparison, grouping, statistical analysis, scientific abstraction, logical synthesis.

The research is based on theoretical dogmas as well as scientific and practical methods carried out by the world's leading economists. Their practical ideas concerning the ecological and economical evaluation of Azerbaijan's natural and resource potential have been reflected in studies by A.A. Nadirov and F.S. Adygozalov.

As decided by the State of Azerbaijan for purposes of the effective distribution of productive powers and industrial structure enhancement, A.A. Nadirov deepened his studies in the 1970s. In 1976, he published the monograph [4]. In his subsequent works, A.A. Nadirov defined how to improve specialization, comprehensive and effective industry development in economic regions in the near and distant future, optimal industry placement. From this point of view, as it was published in the 1970s and the 1980s, the republic's industry was considered to have limited options to produce local raw materials and develop much profitable industries. Therefore, it was necessary to establish a comprehensive approach to recycling many local raw materials used in the country. A.A. Nadirov was convinced

\footnotetext{
${ }^{7}$ State Statistical Committee of the Republic of Azerbaijan, Azerbaijan Regions Official Publication - Statistical summary. SSCRA, SYA, 2018, p. 103.

URL: https://www.stat.gov.az/source/regions/

${ }^{8}$ The Agriculture of Azerbaijan. State Statistical Committee of the Republic of Azerbaijan. Statistical Yearbook of Azerbaijan. Baku, SSCRA, SYA, 2019, 644 p. URL: www.stat.gov.az
}

not only in the necessity, but also in ways of achieving a better level of the comprehensive approach and improving the specialization in regions and in the republic in general [5-7]. Nowadays, when market relations in Azerbaijan are in steady progress, the questions investigated by A.A. Nadirov remain relevant.

F.S. Adygozalov's studies were widely acclaimed for the complexity of issues he had covered, having precise theoretical, methodological and practical implications. The Main Trends for Development and Placement of Productive Powers in the 1970s-1990s in the Azerbaijan $S S R$ were issued by the Institute of Economics of the State Committee for Planning in Azerbaijan. F.S. Adygozalov conducted extensive studies on the effective usage of national lands in each economic region, elaborating the land balance. He provided an economic assessment of soil with regards to its fertility in each specific economic region and investigated forms of technical maintenance and effective organization of agriculture. F.S. Adygozalov conducted scientific researches on water problems as well and scientifically justified the effectiveness of constructing many water bodies in different regions of our country [8].

Some contribution to studies into the development of the economic regions' potential was made by N.A. Nabiyev [9-12].

It is important to mention that the natural resource potential of the Republic of Azerbaijan has been widely studied and assessed comprehensively from economic and environmental perspectives. However, there has not been conducted a thorough analysis of the nature and environment and their influence on the development level of a given economic region. Therefore, there is a dire need for studying the ecological and economical situation in the region, identifying its natural and resource potential. The content, volume and quality of natural resources and reserves and their exploration degree have impact on possibilities of their exploitation and 
their use in the production of materials and the formation of investment resources [13].

\section{Results}

Soil and mineral resources are limited. Regardless of the ownership form, land is a common treasure. It is important to note that neither natural treasure on the planet is not as economical in its integral characteristics as land ${ }^{9}$. The use of land resources is very diversified. The multiple use of land resources depends on functions and types of soil. Soil types in the Ganja-Gazakh Economic Region are formed while being affected by terrain features and soil forming processes - mountainous and valley soil. The mountainous and valley soils, which are widely spread in the region, may be classified into the following soil types, i.e. brown grasslands, mountainous grassland steppe, carbonate mountainous grassland, peat mountainous grassland, dark and regular grey-brown soils, light grey-brown soils. Evaluating the soil, it is necessary to take into consideration natural, climate and environmental factors, as well as economic markers that affect the land use. Hence, Azerbaijan performed the land cadaster zoning. A cadastre region unites territorial units that have a relatively endogenous algorithm, geographic, morphological, meliorative and natural technological conditions influencing the intensification and specialization of the agricultural production ${ }^{10}$. Considering natural agricultural provinces and land cadaster regions of the Republic of Azerbaijan, the Ganja-Gazakh economic region can be mainly attributed to the small Caucasian agricultural region. The region mostly contains dry steppe landscapes, middle grasslands. Grey grass, dark grey-brown and moisture grass are widespread. Soil salinity is

\footnotetext{
${ }^{9}$ Food and Agriculture Organization of the United Nations. Land and Water Division Working Paper. Land Resource Planning for Sustainable Land Management. Rome, FAO, 2017. URL: http://www.fao.org/3/a-i5937e.pdf

${ }^{10}$ On Approval of the Administrative Regulation on Electronic Services Provided by the Ministry of Ecology and Natural Resources of the Republic of Azerbaijan. Baku Ministry of Ecology and Natural Resources of the Azerbaijan Republic. DECISION No. 01-Q, April 17, 2013. - URL: http://www.eqanun.az/alpidata/framework/data/25/f_25790.htm
}

observed too. The region's environment is suitable for crops and raising livestock ${ }^{11}$. The cultivated crop area reflects basic specializations - grain cultivation and potato farming, vegetable farming, gardening (Fig. 1). The Ganja-Gazakh Economic Region plays an important role in the national economy for its agricultural production. The agricultural land area covers 724,886 hectares, or $58.9 \%$ of the total area of the region, with $24.8 \%$ planted. The other specialization of the Ganja-Gazakh Economic Region includes husbandry, e.g. cattle and small livestock raising, poultry and bee farming (Fig. 2). Pastures take 474,991 hectares, or $38.6 \%$ of the region's total area.

The total area unused in the agriculture constitutes 378,077 hectares, or $30.7 \%$ of the region's total area. Approximately $60 \%$ of the cultivated area is used for grains and cereals, including wheat (35.9\%), vegetables and gardening, potatoes and sugar beet (37.2\%). Growing indicators can be observed mainly in cotton, potato production and viticulture. In order to increase agricultural productivity, comprehensive actions are needed to protect the soil and maintain its humidity, especially due to the fact that the land in the Ganja-Gazakh valley are mostly dried dark grey-brown (hazel). These lands are used for weeds, that is why there are more pastures in the region and others. In the Dashkesan and Gadabay regions, favorable conditions for buckwheat cultivation were created.

The forestry and shrubs sector constitute 116,049 hectares, or $9.4 \%$ of the region's total area. Forests are one of the most important resources. Forests play an indispensable role in life protection, oxygen and carbon balance, biodiversity of some chemical elements, climatic conditions in numerous geographical zones, creation of water in atmosphere, soil humidity as well as in rivers and lakes maintenance [14].

\footnotetext{
${ }^{11}$ The Agriculture of Azerbaijan. State Statistical Committee of the Republic of Azerbaijan. Statistical Yearbook of Azerbaijan. Baku, SSCRA, SYA, 2019, 644 p. URL: www.stat.gov.az
} 
A vital feature of forest resources is their multipurpose use. Forest resources are the source for raw materials, health, sanitation, field fences and water restraining barriers. [15] In the GanjaGazakh economic region, the forest area is below country's average. Thus, forests in Azerbaijan constitute $12 \%$ of the total area and this indicator for the region makes 9,5\% (119,228 hectares). The forest areas are spread unevenly in the region: it is enough to say that from eleven administrative units of the region the total forest area in Tovuz (27,267 hectares), Dashkesan (25,377 hectares), Gadabay (21,914 hectares) and Goy-Gol (17,071 hectares) districts constitutes $76.9 \%$ of the region's forest area.

It is important to note that the Ganja-Gazakh Economic Region strongly differs from other economic regions of the Republic of Azerbaijan due to its rich diversity of mineral resources. Located in the Dashkesan district, the Zeylik aluminum ore deposit is one of the promising deposits in the region. Alunite ore constitutes $29.7 \%$ of the country's total ore stock. During the Soviet times, the Ganja clay pit was exploited with the Zeylik aluminum mines located in the Dashkesan district. The Zeylik alunite ore deposit is exploited as mineral and raw base for the Ganja alumina refinery since 1964 . The geological particularity of the Chovdar deposit, which is located in the Dashkesan district, is widely spread hydrothermally modified formations, presence of polymetallic veins, polymetallic and sulfide occurrences of the earth crust layering. This fact attests to the high promising future of the deposit. Moreover, technical and economic aspects of the underground phase exploitation of the Chovdar sulfide ore deposit is to have been engineered by the end of 2019. According to international standards, as for the quantity of precious metals found in the Chovdar deposit, there are 30 occurrences and unique gold mineralization points, 20 low-sulfide copper and gold ores and 50 copper and polymetallic ores. Rates for gold prices have been rising for the recent years, thus making the exploitation of this deposit very favorable. Therefore, the exploitation of this deposit has a significant role for the region's social and economic development. The involvement of foreign investors and local entrepreneurs could help bring the deposit into the economic turnover.

Being one of the promising deposits located in the Ganja-Gazakh Economic Region, the Gadabay copper ore deposit is considered one of the most important metal ore deposits in the region. The deposit is known to provide raw materials for copper and gold production as such copper contains a high concentration of gold. In 1997, the Azerbaijan government signed a contract with RV Investment Group Services LLS to put this deposit into operation. Some works have been started only recently. However, largescale work hasn't begun yet. A growth in gold prices in the global market has created favorable conditions for the production increase. Thus, the company must carry out additional work to increase the manpower on the sites.

Aydag Zeolite in the Tovuz district is one of the most significant deposits in the region. Natural zeolites extracted here are successfully used in agriculture as they enhance the soil quality, increase the productivity of most plants and are used as inert food supplements in the husbandry sector, aiming to absorb heavy metals and radioactive substances from animals' bodies, as well as cleansing harmful contaminants from industrial wastes, improving the gasoline quality, in oil production, as catalyst in oil and chemistry processes, in rubber, plastic and paper sector, in filtering systems at purifying stations and in health care [16].

Clay and gilded deposits are mostly discovered in flat areas [17]. Local people have been using the raw material since ancient times to produce burnt bricks, water-pipes, ceramics [18]. However, those brick and ceramic factories that are still functioning are old, demonstrating low production capacities, with furnace temperatures and brick production and drying technologies being outdated and failing to meet modern needs. The most important clay and gilded deposits in the region are found in the districts of Shamkir, Gazakh, Ashagy Oksyuzlyu (Lower Oysuzlu), 
Yukary-Oysyuzlyu (Upper Oysuzlu), Tovuz and Gadabay. To use capacities of the deposit efficiently, raw material preparation technologies should be modernized by operating more modern highly production machines and equipment [19]. Reviewing the investment attractiveness of these territories and investment risks, it is crucial to conduct the geological and economical evaluation production to further investigate and comprehensively use mineral and fuel resources in the region. The economic and ecological analysis of the quantity and quality of mineral resources from economic and environmental perspectives is an integral part of economic forecasting [20]. For the current and prospective industrial development oriented to the utilization of mining resources, taking into consideration environmental protection the feasibility study of the efficient and thorough usage of relevant natural resources is performed [21]. These documents are considered to be a critical factor for economic forecasting from geological, economical and ecological point of view [22]. These documents aim to provide the technical and economical rationale for mining development and further progression of the relevant sector. Economic forecasting is a key part of economics and helps achieve predictable results in corporate development [23]. With the transition to the market economics it is possible to intelligently predict the participation of foreign companies in the development and utilization of mineral resources as part of a common state production program. For this, it is necessary to study the placement regularities of different kinds of mineral raw materials, assess the geological, macro- and microeconomic structure of the region's promising provinces, as well as forecast mineral reserves.

The assessment of mineral reserves across the region's districts, their location and level of exploration, industrial resources per category, distribution of mineral resources and technical indicators shape characteristics of the region's potential (Table 1). Marble is one of the most valuable construction materials and its usage grows. However, the usage level of local building materials remains unfit for modern needs. The marble deposits are located in the foothills of the Ganja-Gazakh Economic Region, with the total volume of 100 million tonnes. Most of these deposits are located in the zones reachable by transport. Their production and use as much as needed nowadays could cover most of the country's demand for marble.

The specialization of the region characterizes its main economic base with regards to the mineral resources use (Fig. 3).

To forecast the use of primary and secondary mineral raw materials within a country (region), it is required to analyze the economic, geological, technological and ecological information in the relevant regional industrial systems [24]. The current and future development of economic branches both nationally and regionally depends on the effective use of active production funds, qualitative and quantitative assessment of mineral resources. It is particularly important to consider the time for the use of productive capacities and production funds of enterprises specializing in rock mining and production of non-metallic construction materials. Metallic construction materials are produced to reduce the time it takes to prepare the raw materials for the production and provision of raw material supplies for the enterprise in order to maximize the coefficient of production capacities use. The depletion of productive resources in mining depends not only on their quantity but also on the operational system and the effective system organization.

Depending on production capacities of an enterprise, technological methods, comprehensive use of raw materials, the service life of mining in terms of time and place could be greatly increased. On the other hand, it is also possible to raise the labor productivity, reduce losses and widen cooperation by effectively using raw materials. The economic assessment of raw materials for differential rent plays a significant role in this process. It is noteworthy that the productivity of sand quarries depends not only on their reserves, treatment and production methods, but also on the availability of accessible methods 
for the delivery of raw materials to consumers. However, a lack of accessible methods and appropriate specialized transportation means often makes the delivery cost increase per $1 \mathrm{~m}^{3}$ of raw materials. Dealing with construction materials production in the Ganja-Gazakh Economic Region, enterprises do not fully satisfy economic needs and population with required materials. To address the region's needs for construction materials and eliminate additional transport costs for their import from other regions, investments in the local river, rock, sand, clay, automobile, gravel and ferroconcrete products must be attracted in Tovuz, Ağstafa, Shamkir, Goranboy districts. Moreover, despite having significant lime reserves in the region, most part of the cubic rock is imported from other economic regions, for example from the Absheron Economic Region with the double price if compared to the local lime. The efficient use of local limestone mining sites is linked with the implementation of equipment that reduces transportation costs. This could also influence the labor and raw material production.

It is also important to note that the Ganja-Gazakh Economic Region is not so selective in terms of its energy resources, which may be considered as a negative factor for the development of the region's economy. In the 1960s and 1970s, the geological survey confirmed rich oil fields especially near Djeyranchel. Nevertheless, a lack of appropriate extraction methods for these layers and high oil flow rates impeded the exploitation of these fields. In the meantime, there are small oil reserves concentrated near Naftalan, Gazanbulaq and Tartar, but they will not make a considerable contribution to fuel and energetic balance of the country.

\section{From Problems to Investment Attractiveness}

Non-ferrous metal industry, light and local industry, quarries located in the Ganja-Gazakh region of Azerbaijan are sources of serious contamination, as they dump their wastes in the environment. Industrial wastes in the western region of the country were documented by the Ganja Science Center. While preserving usable agricultural lands, such concentration of wastes collected from different districts of the GanjaGazakh Economic Region causes that they remain unused, and pollutes the environment. During the exploitation and recycling of natural resources, the greater part of rock materials is dumped to rivers and streams across the districts, which severely hampers water, land and plant resources.

The only way to eliminate the damage done to the society and nature during production and recycling processes is to produce new cheaper building materials from these wastes or to create a waste-free or low-waste production, thus supporting the comprehensive environment protection and eliminating ecological problems in the region. Significant results are guaranteed if these measures are taken in an effective manner and supported with investment. During the exploitation of the Dashkesan mining and enrichment plant, the greater part of the territory was devastated. While extracting raw materials, a part of the soil cover got under unearthed rocks and the other part became useless because it got mixed up with stones, severely affecting the wildlife and vegetation. It is obvious that the rehabilitation of the lands affected by such actions is mandatory. While conducting soil improvement the measures must taken in two steps: technical rehabilitation and biological rehabilitation. Soil conservation, restoration of soil fertility, effective soil use and conditions for the reproduction in the region require comprehensive responses. The region's land for mining must be used after preliminary exploration of land resources on the Do Not Harm basis. Environmental conditions in the Ganja-Gazakh region are still very tense, since it is one of the regions exposed to the anthropogenic impact.

\section{Discussions}

The weak investment promotion, the insufficient balance of interests from the investment process and inadequate regional investment policy and poor environmental protection are major causes of the non-effective use of natural resources in 
the Ganja-Gazakh region. The natural resource potential of the region can be assessed by evaluating the potential investment target.

\section{Conclusion}

The natural and resource potential of the GanjaGazakh Economic Region, including the local terrain, mineral, land, natural and recreational resources stimulate the industrial development, agriculture and other economic sectors. Although there is a possibility to widely use the rich natural and resource potential of the economic region, its practical use is very low. The utilization of the natural and resource potential is seriously affected due to the considerable environmental damage and the fact that the main priority is to care about consumers. In this case, the effective, comprehensive utilization of primary sources of raw materials is pushed into oblivion and no one is responsible for economic and environmental damage. Financial needs for further progress towards the comprehensive use of primary and secondary raw materials, low-waste technology use significantly outstrip the governmental capacity to meet them. This requires a systematic involvement of private funding sources. The main objective of the efficient use of the natural and resource potential of the Ganja-Gazakh Economic Region is to detect, control and fight against the pollution of facilities and resources in this region. Given the intensity of the ecological and economic damage due to excessive emissions, it would be useful to consider applying both legal and economic sanctions. It is necessary to assure the economic management of the region with respect to environmental factors, namely: a) inclusion of environmental factors into the region's modern economic development mechanism; b) development of a mechanism for investment to influence the region's economy in order to create and sustain the ecological and economic balance.

Table 1

Assessment of the potential and use of construction rocks of the Ganja-Gazakh Economic Region

\begin{tabular}{|c|c|c|c|c|c|}
\hline \multirow[t]{2}{*}{ Quarries and Deposits } & \multirow[t]{2}{*}{ Use } & \multicolumn{3}{|c|}{ Resources Classification } & \multirow{2}{*}{$\begin{array}{l}\text { Fact of } \\
\text { Usage }\end{array}$} \\
\hline & & Proved & Probable & Possible & \\
\hline \multicolumn{6}{|c|}{ Agstafa sand and gravel quarry } \\
\hline $\begin{array}{l}\text { Near Baku-Tbilisi } \\
\text { highway }\end{array}$ & $\begin{array}{l}\text { Cleaned sand is usable for } \\
\text { production of grinded and } \\
\text { regular concrete. Gravel is } \\
50 \mathrm{~mm} \text { thick in solutions }\end{array}$ & $\begin{array}{l}>15,000 \\
\text { thousand } \mathrm{m}^{3}\end{array}$ & $\begin{array}{l}>2,000 \\
\text { thousand } \mathrm{m}^{3}\end{array}$ & $\begin{array}{l}<500 \\
\text { thousand } \\
\mathrm{m}^{3}\end{array}$ & Not used \\
\hline \multirow{2}{*}{$\begin{array}{l}\text { Shores of the Kura river } \\
\text { located } 12 \mathrm{~km} \text { to the } \\
\text { north-east of the Agstafa } \\
\text { quarry }\end{array}$} & $\begin{array}{l}\text { Sand and gravel are usable } \\
\text { for dam construction }\end{array}$ & $\begin{array}{l}>35,000 \\
\text { thousand } \mathrm{m}^{3}\end{array}$ & - & - & Not used \\
\hline & $\begin{array}{l}\text { Sand and gravel are usable } \\
\text { for road paving and } \\
\text { concrete coatings }\end{array}$ & - & $\begin{array}{l}>4,000 \\
\text { thousand } \mathrm{m}^{3}\end{array}$ & - & $\begin{array}{l}\text { Used on the } \\
\text { left shore }\end{array}$ \\
\hline $\begin{array}{l}\text { Saloglu village near } \\
\text { Agstafa }\end{array}$ & $\begin{array}{l}\text { Sand and gravel are usable } \\
\text { for road paving }\end{array}$ & $\begin{array}{l}<100 \\
\text { thousand } \mathrm{m}^{3}\end{array}$ & - & - & Used \\
\hline $\begin{array}{l}\text { Clay and gravel quarry } \\
\text { not far from Poylu village } \\
\text { near Agstafa }\end{array}$ & $\begin{array}{l}\text { Concrete and sidewalk } \\
\text { construction }\end{array}$ & $\begin{array}{l}<2,000 \\
\text { thousand } \mathrm{m}^{3}\end{array}$ & - & - & Used \\
\hline Eynalli quarry & $\begin{array}{l}\text { Raw materials are usable } \\
\text { for sidewalk construction }\end{array}$ & $\begin{array}{l}>100 \\
\text { thousand } \mathrm{m}^{3}\end{array}$ & - & - & Not used \\
\hline \multicolumn{6}{|l|}{ Agstafa rock quarry } \\
\hline $\begin{array}{l}1 \mathrm{~km} \text { to the north west } \\
\text { from Agstafa }\end{array}$ & $\begin{array}{l}\text { Bricks and ceramics } \\
\text { production }\end{array}$ & & $\begin{array}{l}<30,000 \\
\text { thousand } \mathrm{t}\end{array}$ & & Used \\
\hline $\begin{array}{l}\text { Aydaq quarry not far } \\
\text { from Tatli village }\end{array}$ & Concrete raw materials & $\begin{array}{l}<30,000 \\
\text { thousand } t\end{array}$ & $\begin{array}{l}<100 \\
\text { thousand } \mathrm{t}\end{array}$ & $\begin{array}{l}>3,000 \\
\text { thousand } \mathrm{t}\end{array}$ & Used \\
\hline
\end{tabular}




\begin{tabular}{|c|c|c|c|c|c|}
\hline $\begin{array}{l}\text { Mainstream of Zayam } \\
\text { river }\end{array}$ & $\begin{array}{l}\text { Concrete and sidewalk } \\
\text { construction }\end{array}$ & $\begin{array}{l}<10,000 \\
\text { thousand } \mathrm{m}^{3}\end{array}$ & - & - & Used \\
\hline \multirow[t]{2}{*}{ Basin of Shamkir river } & Sidewalk constructions & $\begin{array}{l}>2,000 \\
\text { thousand } \mathrm{m}^{3}\end{array}$ & - & - & Not used \\
\hline & $\begin{array}{l}\text { Concrete construction } \\
\text { M300, M350 }\end{array}$ & $\begin{array}{l}>1,000 \\
\text { thousand } \mathrm{m}^{3}\end{array}$ & $\begin{array}{l}>1,000 \\
\text { thousand } \mathrm{m}^{3}\end{array}$ & - & Used \\
\hline $\begin{array}{l}\text { Koroglu quarry in } 2.5 \mathrm{~km} \\
\text { to the north-west from } \\
\text { Zayam river }\end{array}$ & Concrete raw materials & $\begin{array}{l}>10,000 \\
\text { thousand } t\end{array}$ & $\begin{array}{l}>3,000 \\
\text { thousand } \mathrm{t}\end{array}$ & - & Not used \\
\hline Chair river quarry & Concrete and road paving & $\begin{array}{l}<300 \\
\text { thousand } \mathrm{m}^{3}\end{array}$ & - & - & Not used \\
\hline \multicolumn{6}{|l|}{ Shamkir rock quarry } \\
\hline $6 \mathrm{~km}$ from Shamkir & $\begin{array}{l}\text { Bricks and ceramics } \\
\text { production }\end{array}$ & $\begin{array}{l}<150 \\
\text { thousand } t\end{array}$ & $\begin{array}{l}<100 \\
\text { thousand } t\end{array}$ & $\begin{array}{l}<100 \\
\text { thousand } \mathrm{t}\end{array}$ & Used \\
\hline $1.5 \mathrm{~km}$ from Shamkir & $\begin{array}{l}\text { Bricks and ceramics } \\
\text { production }\end{array}$ & $\begin{array}{l}<50 \\
\text { thousand } \mathrm{t}\end{array}$ & - & - & Not used \\
\hline \multicolumn{6}{|c|}{ Tovuz sand and gravel quarry } \\
\hline Basin of Tovuz river & $\begin{array}{l}\text { Concrete coatings and road } \\
\text { paving }\end{array}$ & $\begin{array}{l}<5,000 \\
\text { thousand } \mathrm{m}^{3}\end{array}$ & - & - & Used \\
\hline $\begin{array}{l}10-15 \mathrm{~km} \text { to the west of } \\
\text { Tovuz }\end{array}$ & Concrete & $\begin{array}{l}<1,000 \\
\text { thousand } \mathrm{t}\end{array}$ & - & - & Used \\
\hline $\begin{array}{l}\text { Upper Oysuzlu quarry in } \\
\text { the basin of Tovuz river } \\
8-10 \mathrm{~km} \text { from Tovuz }\end{array}$ & Decorative concrete & $\begin{array}{l}<500 \\
\text { thousand } t\end{array}$ & - & - & Used \\
\hline $\begin{array}{l}6-7 \mathrm{~km} \text { from Tovuz river } \\
\text { basin }\end{array}$ & $\begin{array}{l}\text { Bricks and ceramics } \\
\text { constructions }\end{array}$ & $\begin{array}{l}<300 \\
\text { thousand } \mathrm{t}\end{array}$ & - & - & Used \\
\hline \multicolumn{6}{|c|}{ Gadabay sand and gravel quarry } \\
\hline $\begin{array}{l}\text { Kharkhar quarry near } \\
\text { Kharkhar and Laskar } \\
\text { villages }\end{array}$ & $\begin{array}{l}\text { Concrete and sidewalk } \\
\text { construction }\end{array}$ & $\begin{array}{l}<150 \\
\text { thousand } \mathrm{m}^{3}\end{array}$ & - & - & Not used \\
\hline \multirow[t]{2}{*}{$\begin{array}{l}\text { Galakand quarry close to } \\
\text { Galakand village }\end{array}$} & Sidewalk constructions & $\begin{array}{l}<150 \\
\text { thousand } \mathrm{m}^{3}\end{array}$ & - & - & Not used \\
\hline & Construction rock & - & - & $\begin{array}{l}>500 \\
\text { thousand } \mathrm{t}\end{array}$ & Not used \\
\hline $\begin{array}{l}14 \mathrm{~km} \text { north from } \\
\text { Gadabay }\end{array}$ & Building materials & - & - & $\begin{array}{l}<1,000 \\
\text { thousand } t\end{array}$ & Not used \\
\hline $\begin{array}{l}11-12 \mathrm{~km} \text { to the north- } \\
\text { west from Gadabay }\end{array}$ & $\begin{array}{l}\text { Bricks and ceramics } \\
\text { production }\end{array}$ & $\begin{array}{l}>300 \\
\text { thousand } \mathrm{t}\end{array}$ & - & - & Used \\
\hline \multicolumn{6}{|c|}{ Gazakh sand and gravel quarry } \\
\hline $\begin{array}{l}\text { Babakar quarry } 6 \mathrm{~km} \\
\text { from Ali-Bayramli } \\
\text { village }\end{array}$ & Concrete raw materials & $\begin{array}{l}<300 \\
\text { thousand } \mathrm{t}\end{array}$ & - & - & Not used \\
\hline $\begin{array}{l}1,5 \mathrm{~km} \text { from Ali- } \\
\text { Bayramli village }\end{array}$ & Concrete production & & & $\begin{array}{l}>4,000 \\
\text { thousand } \mathrm{t}\end{array}$ & Used \\
\hline $\begin{array}{l}\text { Kangerli quarry } 5,5 \mathrm{~km} \\
\text { south-west from Ali- } \\
\text { Bayramli }\end{array}$ & Construction materials & $\begin{array}{l}>300,000 \\
\text { thousand } \mathrm{t}\end{array}$ & - & - & Used \\
\hline Demirchiler quarry & Construction materials & $\begin{array}{l}>10,000 \\
\text { thousand } \mathrm{t}\end{array}$ & - & - & Not used \\
\hline Gazakh rock quarry & $\begin{array}{l}\text { Bricks and ceramics } \\
\text { production }\end{array}$ & $\begin{array}{l}>4000 \\
\text { thousand } \mathrm{t}\end{array}$ & - & - & Not used \\
\hline $\begin{array}{l}\text { Gazakh rock quarry 3-4 } \\
\text { km from Dashsalahli } \\
\text { village }\end{array}$ & Construction rock and lime & $\begin{array}{l}>20,000 \\
\text { thousand } \mathrm{m}^{3}\end{array}$ & - & $\begin{array}{l}<1,000 \\
\text { thousand } \\
\mathrm{m}^{3}\end{array}$ & Used \\
\hline \multicolumn{6}{|c|}{ Molladjalilli sand and gravel quarry } \\
\hline Near Molladjalilli village & $\begin{array}{l}\text { Sand and gravel are usable } \\
\text { for concrete and road } \\
\text { paving }\end{array}$ & $\begin{array}{l}<500 \\
\text { thousand } \mathrm{m}^{3}\end{array}$ & - & - & Not used \\
\hline
\end{tabular}

Source: Authoring, based on the Ministry of Ecology and Natural Resources of the Republic of Azerbaijan data. URL: http://eco.gov.az/ 


\section{Figure 1}

\section{Crop production area in 2019, hectare}

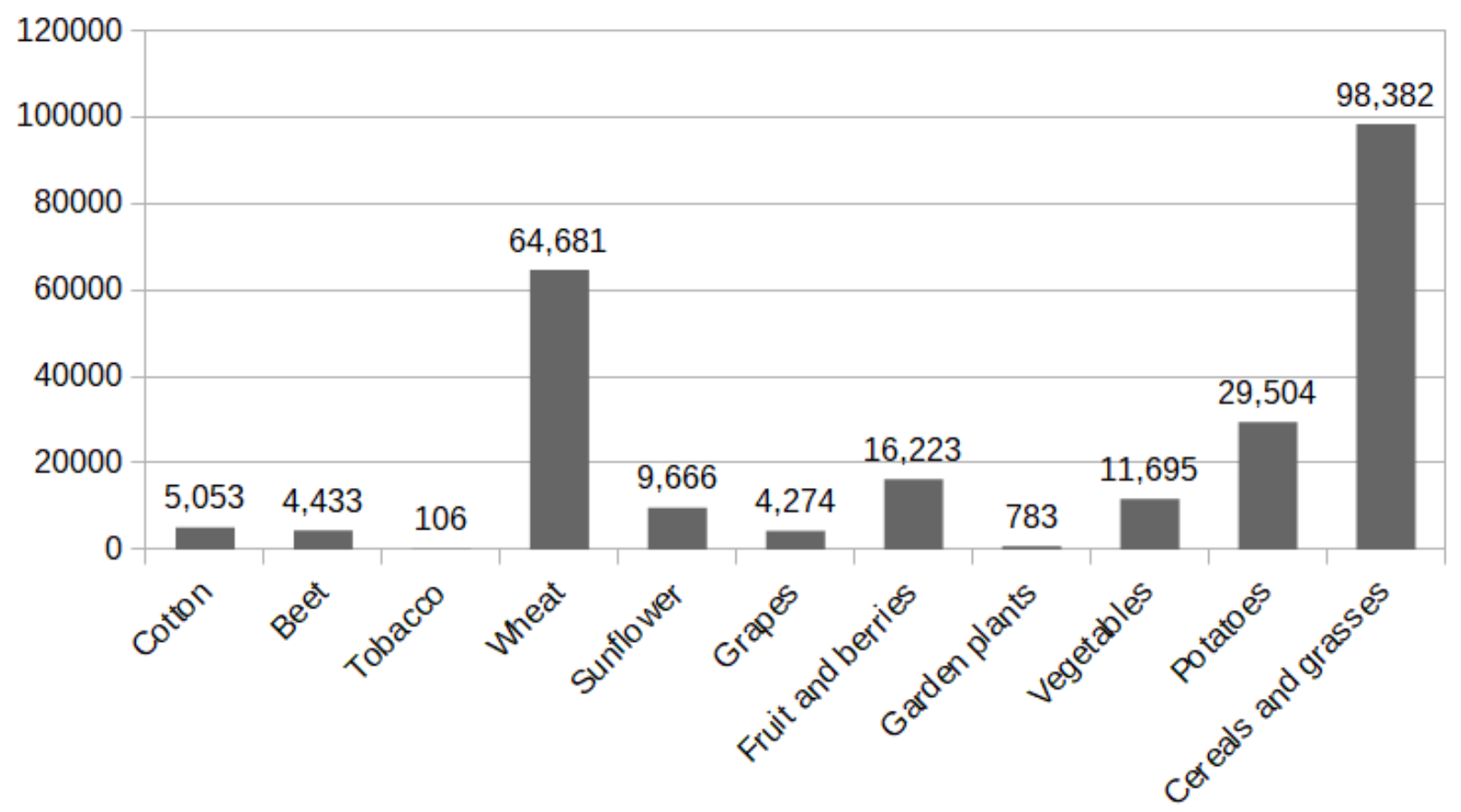

Source: The State Statistical Committee of the Republic of Azerbaijan data. URL: https://www.stat.gov.az/source/regions// 


\section{Figure 2}

Livestock farming in 2019, animal units

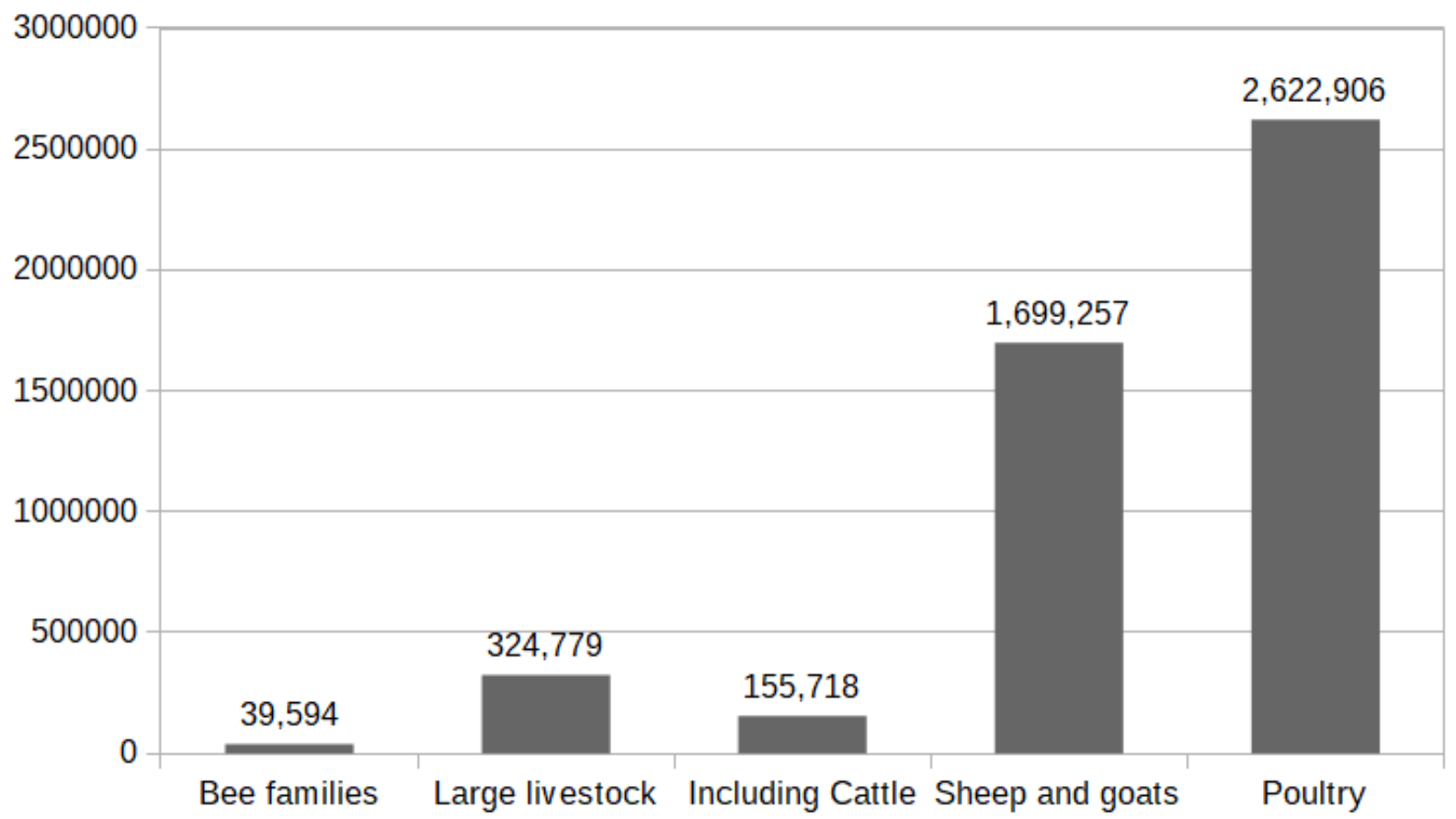

Source: The State Statistical Committee of the Republic of Azerbaijan data. URL: https://www.stat.gov.az/source/regions//

\section{Figure 3}

The reserves of mineral raw materials of the Ganja-Gazakh Economic Region in terms of use, thousand Azerbaijan Manat

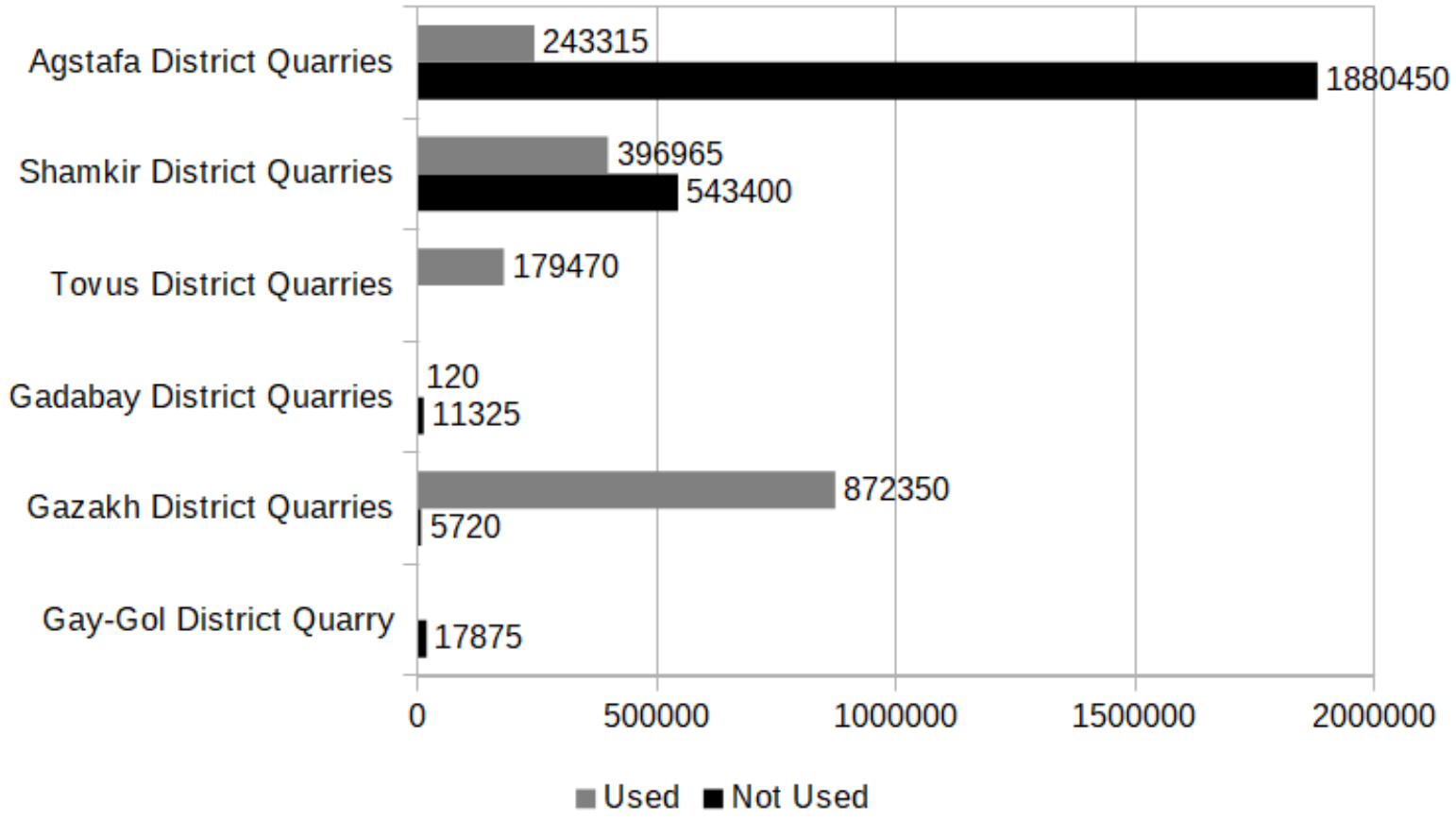

Source: The Ministry of Ecology and Natural Resources of the Republic of Azerbaijan data.

URL: http://gsaz.az/articles/view/92/Azarbaycanin-faydali-qazintilari 


\section{References}

1. Nuriyev O. Problems of Sustainable Development of the Economy of Azerbaijan. UNEC SABAH Azərbaycan Dövlət iqtisad Universiteti, 2018.

URL: http://unec.edu.az/application/uploads/2018/12/Nuriyev-Orxan.pdf

2. Asadov I. Productivity and Competitiveness Caucasus and Central Asia. National Confederation of Entrepreneurs (Employers') Organizations of Azerbaijan Republic, 2007.

URL: https://www.ilo.org/wcmsp5/groups/public/---ed_dialogue/--act_emp/documents/publication/wcms_593313.pdf

3. Andersen A.D., Marin A., Simensen E.O. Innovation in Natural Resource-Based Industries: A Pathway to Development? Introduction to Special Issue. Journal Innovation and Development, 2018, vol. 8, iss. 1, pp. 1-27. URL: https://doi.org/10.1080/2157930X.2018.1439293

4. Nadirov A.A.. Azərbaycanda sənayenin səmərıli yerləşdirilməsinin iqtisadi problemləri. Bakı, Elm, 1976, p. 159.

5. Nadirov A.A., Muradov Sh.M., Nuriyev A.H., Huseynov T.T. Ekonomika Azerbaidzhana [The economy of Azerbaijan]. Baku, Elm, 2003, p. 341.

6. Nadirov A.A. Müstəqillik regionların tarazlı sosial-iqtisadi inkişafında mühüm şərtdir. Bakı, Xalq qəzeti, 2010, p. 3. URL: http://www.anl.az/down/meqale/xalqqazeti/2010/mart/111082.htm

7. Nadirov A.A. Azərbaycan iqtisadiyyatının daima yüksələn müstəqillik dövrü. Bakı, CBS Polygraphic Production, 2012, p. 359.

8. Adygozalov F.S. et al. Kənd təsərrüfatında sudan səmərəli istifadə edilməsi problemləri. Bakı, Azərnəşr, 1987, p. 136.

9. Nəbiyev N.Ә. İqtisadiyyat, cəmiyyət və ekoloji mühit. Baku, Nurlan, 2000, p. 696.

10. Allahverdiyev N.B., Gafarov K.S., Ahmadov A.M. Strategic Planning. Baku, Nasir, 2004, p. 214.

11. Mamedov G.S. Socioeconomic and environmental foundations for the efficient use of land resources in Azerbaijan. Baku, Elm, 2007, 854 p.

12. Atakishiyev M.J. Environmental economics. Baku, Elm, 2004, 220 p.

13. Ahmadov N. Comparative Estimation of Ecological Rent in Absheron and Sheki-Zagatala Economic Regions of Azerbaijan Republic European. Journal of Sustainable Development, 2017, vol. 6, iss. 4, pp. 81-94. URL: https://doi.org/10.14207/ejsd.2017.v6n4p81

14. Gibson C., McKean M.A., Ostrom E. Explaining Deforestation: The Role of Local Institutions. In: Forest Resources and Institutions Forests, Trees and People Programme. Working Paper No. 3. Forestry Department, 1998. URL: http://www.fao.org/3/x2104e/X2104E00.HTM\#TopOfPage

15. Hosny El-Lakany M. Green Facts Facts on Health and the Environment Measuring Progress towards Sustainable Forest Management. 2005. URL: https://www.greenfacts.org/en/forests/1-3/1forests-sustainable-assessment.htm\#0p0

16. Stocker K., Ellersdorfer M., Lehner M., Raith J.G. Characterization and Utilization of Natural Zeolites in Technical Applications. BHM Berg-und Hüttenmännische Monatshefte, 2017, vol. 162, iss. 4, pp. 142-147. URL: https://doi.org/10.1007/s00501-017-0596-5

17. Pozo M., Calvo J.P. An Overview of Authigenic Magnesian Clays. Minerals, 2018, vol. 8, iss. 11, p. 520. URL: https://doi.org/10.3390/min 8110520 
18. Petrie K., Livingstone A. The Ceramics Reader. Bloomsbury Academic, 2017, 616 p.

19. Lissy M.P.N., Peter C., Mohan K., Greens S., George S. Energy Efficient Production of Clay Bricks Using Industrial Waste. Heliyon, 2018, vol. 4, iss. 10.

URL: https://doi.org/10.1016/j.heliyon.2018.e00891

20. Khusainova S.V., Bakhvalov S.Y. A Regional System to Forecast the Social-Economic Development: The Case of the RF Regions. European Research Studies Journal, 2018, vol. XXI, iss. 1, pp. 588-601. URL: https://www.ersj.eu/dmdocuments/2018_XXI_1_48.pdf

21. Shahbazi S. Sustainable Manufacturing through Material Efficiency Management. Stockholm, Sweden Mälardalen University Sweden, School of Innovation, Design and Engineering, Innovation and Product Realisation, 2018, p. 72.

22. Elliott G., Timmermann A. Economic Forecasting. Princeton University Press Princeton and Oxford, 2016.

23. Bourguignon D., Opri-Ilmatar Orenius Members' Research Service. European Parliamentary Research Service, 2018, p. 8. URL:

https://www.europarl.europa.eu/RegData/etudes/BRIE/2018/625180/EPRS_BRI(2018)625180_EN .pdf

24. Carvalho F.P. Mining Industry and Sustainable Development: Time for Change. Food and Energy Security, 2017, vol. 6, iss. 2, pp. 61-77. URL: https://doi.org/10.1002/fes3.109

\section{Conflict-of-interest notification}

We, the authors of this article, bindingly and explicitly declare of the partial and total lack of actual or potential conflict of interest with any other third party whatsoever, which may arise as a result of the publication of this article. This statement relates to the study, data collection and interpretation, writing and preparation of the article, and the decision to submit the manuscript for publication. 